\title{
Carbon and water dynamics of a bioenergy crop (Cynara cardunculus L.) under different meteorological conditions in a semi-arid region
}

\author{
Gianfranco Rana, Rossana M. Ferrara, Cristina Muschitiello \\ Council for Agricultural Research and Economics, Agriculture and Environment Research Center, Bari, Italy
}

\begin{abstract}
To evaluate the environmental adaptability of cultivated cardoon (Cynara cardunculus L.) its water use efficiency [(WUE) ratio between net ecosystem exchange (NEE) and evapotranspiration (ET)] was analysed. The crop was cultivated in South Italy and WUE was evaluated at different time scales during two seasons: wet and dry. Even if the crop development is similar in the two seasons, plants delay their development in the presence of drought, showing, in this way, an improvement in their adaptability. Seasonal WUE in the dry season is greater than in the wet one by $+11.2 \%$, and this is also confirmed at monthly and daily scale. Hourly analysis around the full development phase shows that WUE is greater during the wet season than during the dry one, this being explainable when considering the impact of the drivers [(photosynthetically active radiation (PAR), vapour pressure deficit (VPD), and air temperature $\left.\left(T_{\text {air }}\right)\right]$ on $\mathrm{CO}_{2}$ and $\mathrm{H}_{2} \mathrm{O}$ exchanges by stomatal regulation. The saturation values of NEE in function of PAR (threshold 2.5 $\mathrm{MJ} \mathrm{m}^{-2} \mathrm{~h}^{-1}$ ) and VPD (threshold 10 $\mathrm{hPa}$ ) are greater during the wet season than the dry one.
\end{abstract}

\footnotetext{
Correspondence: Rossana M. Ferrara, Council for Agricultural Research and Economics, Agriculture and Environment Research Center, via C. Ulpiani 570125 Bari, Italy.

E-mail: rossana.ferrara@crea.gov.it
}

Key words: Biomass crop; Climatic drivers; Mediterranean climate; Photosynthetically active radiation; Vapour pressure deficit.

Acknowledgments: the research was carried out under the National Research Project Optimization of existing bioenergy chains for econom$i c$ and environmental sustainability (BIOSEA) and E-A-OR Collections.

Funding: Ministry of Agriculture, Food and Forestry Policies (MiPAAF), Italy. The crop data were kindly supplied by Dr. Angelo Domenico Palumbo and Dr. Laura D'Andrea. The authors thank Nicola Martinelli for management of experimental devices.

Received for publication: 2 November 2016

Revision received: 24 April 2017.

Accepted for publication: 29 April 2017

(C) Copyright G. Rana et al., 2017

Licensee PAGEPress, Italy

Italian Journal of Agronomy 2017; 12:862

doi:10.4081/ija.2017.862

This article is distributed under the terms of the Creative Commons Attribution Noncommercial License (by-nc 4.0) which permits any noncommercial use, distribution, and reproduction in any medium, provided the original author(s) and source are credited.
Furthermore, also the linear relationships between ET and PAR and VPD showed higher slopes in the wet season than in the dry one. Drought causes reduction in both photosynthesis and evapotranspiration by stomatal regulation, however, the photosynthesis process is surely more sensitive to water stress than the crop transpiration, thus demonstrating the good adaptability of this crop to scarce water availability of semi-arid conditions.

\section{Introduction}

The knowledge of the relationships between environment and ecosystem is crucial for assessing the adaptability of crops devoted to bioenergy production (Vanloocke et al., 2012). To maximize bioenergy feedstock production, the resource use efficiency of such crops has to be investigated in order to know their sensitivity to different environmental and climatic conditions.

The primary goal of advanced renewable bioenergy production is to decrease greenhouse gas emissions, therefore the mandatory requirements to establish environmental adaptability of a bioenergy crop are: (i) to establish its carbon (C) source-sink nature and (ii) to evaluate the environmental resources capability to support its optimal growth in a given ecosystem. The eddy covariance (EC) technique can be employed for these purposes, performing measurements at the ecosystem level of both water vapour $\left(\mathrm{H}_{2} \mathrm{O}\right)$ and carbon dioxide $\left(\mathrm{CO}_{2}\right)$ fluxes (Baldocchi, 2003), which represent the starting points for the direct evaluation of evapotranspiration (ET) and net ecosystem exchange (NEE), respectively. Furthermore, by means of these two variables, the water use efficiency (WUE) can be computed for assessing the capability of a crop to suitably use water during the growth cycle and, also, for evaluating its adaptability (Katerji et al., 2008; Rana et al., 2016a). The literature is rich of examples relative to ecosystem WUEs, defined in terms of net carbon uptake by the ecosystem per amount of water loss as ET, both obtained by EC measurements [Li et al., 2015 - vineyard; Wagle and Kakani 2012 - switchgrass; Tallec et al., 2013 - winter wheat and maize; Zeri et al., 2013 - biofuel (row crops, Miscanthus, Switchgrass, native prairie); Shurpali et al., 2013 - reed canary grass, a perennial bioenergy crop]. Wagle and Kakani (2012) summarized different metrics for defining the ecosystem WUE at different time scales (from seasonal to instantaneous scale) by EC measurements. This approach can be helpful to gain insight into environmental and eco-physiological mechanisms of carbon and water (Yu et al., 2008).

The current change of regional precipitation regime, both in terms of rainfall intensity and distribution, is well established all over the world. In the Mediterranean basin this issue was investigated by many studies (Giorgi and Lionello, 2008; Rana et al., 2016b; Katerji et al., 2017). The scarcity of surface soil water following periods of long drought increases stomatal resistance, and decreases the plants' photosynthetic capacity (Polley et al., 2011). 
Some studies showed that the soil water availability is an important limiting abiotic factor for NEE light response and productivity (Pinigintha et al., 2010; Zhang et al., 2014), so the increased frequency of dry periods may decrease NEE light responses whose changes in different weather conditions has to be investigated.

By means of three years of continuous EC measurements, Rana et al. (2016a) demonstrated that a rain-fed bioenergy crop, Cynara cardunculus L. var. altilis DC. (in the following indicated cultivated cardoon), cultivated in South Italy, requires one season for its establishment, being C-neutral during the first year, $\mathrm{C}$-sink and $\mathrm{C}$-source in the second and third year, respectively. Moreover, cultivated cardoon showed an improvement in its use of water and $\mathrm{CO}_{2}$ assimilation during the successive growing seasons.

In this study, the role of environmental drivers on water and carbon cycles is investigated for this innovative dedicated energy crop. More precisely, in order to understand how the water use efficiency of the cultivated cardoon varies with environmental conditions (in the sense of weather and water availability), $\mathrm{CO}_{2}, \mathrm{H}_{2} \mathrm{O}$ fluxes and WUE at seasonal, monthly, daily and hourly time scales are analysed during two contrasting growing seasons, one wet and one dry, investigating how the drivers of actual crop evapotranspiration and $\mathrm{CO}_{2}$ assimilation (i.e. vapour pressure deficit, VPD, air temperature and light) influence the plant-water-atmosphere relationships. Indeed, cultivated cardoon is able to growth without supplying water and literature reports its good adaptability to drought conditions (Gominho et al., 2011), with high yields (Grammelis et al., 2008). Therefore, its employments for biofuel feedstock production could be promising in arid and semi-arid environments, which cover $30 \%$ of the global land surface (Asner et al., 2003), where the major production limit is water. The questions to address are if and how the variability of actual climatic conditions affects the potentiality of this bioenergy crop, cultivated in semi-arid conditions, in a context of climate changes (Katerji et al., 2017). In particular, considering the increasing of drought around the world (Dai et al., 2004), the effect of drought on carbon and water cycles should be better understood for evaluating the sustainability of this bioenergy crop, despite the future climate changes.

The main aim of this work is to study the adaptability of cultivated cardoon crop to semi-arid environment, in particular: (i) to investigate the relationships between WUE (as ratio between NEE and ET) and VPD, light/radiation and air temperature at seasonal, monthly, daily and hourly scales during two seasons, one wet and one dry; (ii) to investigate how the stomatal regulation influences the crop photosynthesis and evapotranspiration under different crop water conditions.

\section{Materials and methods}

\section{The site and the crop}

The trial was carried out in a field of about 2 ha in the CREAAA Research Unit experimental farm located in southern Italy (Rutigliano-Bari, $41^{\circ} 01^{\prime} \mathrm{N}, 17^{\circ} 01^{\prime} \mathrm{E}$, altitude $147 \mathrm{~m}$ a.s.1.). The climate is Mediterranean semi-arid, with mild winters and warmdry summers: the rain is $552 \mathrm{~mm}$ year $^{-1}$ mainly distributed between the autumn and the late winter. The soil (Lithic Rhodoxeralf) characteristics are in Table 1.

A cultivated cardoon selected at the Polytechnic University of Madrid for its adaptability to semi-arid environments was sown on 31 th October 2009 with a plant density of 30,000 plants ha ${ }^{-1}$ and an inter-row spacing of $1.2 \mathrm{~m}$. Main tillage was conducted in the autumn 2009 as medium-depth ploughing $(0.3 \mathrm{~m})$. Seedbed preparation was conducted immediately before sowing, by a pass with a disk harrow. Pre-plant fertiliser was distributed at a rate of 100 $\mathrm{kgP}_{2} \mathrm{O}_{5 \mathrm{ha}^{-1}}$ (triple superphosphate). Starting from the second growing season, the crop was managed with low inputs, by avoiding soil tillage and mineral fertilisation. No water was applied as irrigation so that the cardoon regrew immediately after the first rain in autumn.

Since bioenergy crops should be managed with low inputs, no water was applied during three growing seasons. The fresh and dry weight of biomass and the leaf area index (LAI) were measured by destructive sampling; the phenological stages were registered following Archontoulis et al. (2010). The aboveground biomass was harvested in summer when the crop was completely dry (Rana et al., 2016a).

\section{Flux and ancillary measurements}

$\mathrm{H}_{2} \mathrm{O}$ and $\mathrm{CO}_{2}$ fluxes were measured by means of the EC method (e.g. Kaimal and Finnigan 1994), using a three-dimensional sonic anemometer (USA-1, Metek GmbH, Elmshorn, Germany) and a fast-responding open-path infrared $\mathrm{CO}_{2} / \mathrm{H}_{2} \mathrm{O}$ gas analyser (IRGA, LI-7500, Li-COR Inc., Lincoln NE, USA). A detailed description of the setup is given in Rana et al. (2016a). Data were collected continuously on an Industrial Computer (Advantech, USA) by a resident software (MeteoFlux, Servizi Territorio, S.n.c., Cinisello Balsamo, Italy) at $10 \mathrm{~Hz}$ frequency.

The turbulent fluxes of $\mathrm{CO}_{2}\left(F c, \mu \mathrm{mol} \mathrm{m}{ }^{-2} \mathrm{~s}^{-1}\right), \mathrm{H}_{2} \mathrm{O}\left(\mathrm{mmol} \mathrm{m}^{-2} \mathrm{~s}^{-1}\right)$, sensible heat $\left(H, \mathrm{~W} \mathrm{~m}^{-2}\right)$, latent heat $\left(\mathrm{LE}, \mathrm{W} \mathrm{m}^{-2}\right)$ were calculated by using the EddyPro ${ }^{\circledR}$ software (http://www.licor.com/ eddypro), implementing double coordinate rotation (Kaimal and Finnigan 1994), 60 minutes block averaging, statistical tests (Vickers and Mahrt, 1997), density correction (Webb et al., 1980), maximum cross-covariance method and spectral corrections (Moncrieff et al., 1997). Various filters for selecting good quality data were applied following Mauder and Foken (2004), Reichstein et al. (2005) and Papale et al. (2006). The $\mathrm{CO}_{2}$ storage was estimated using the single point method (Moureaux et al., 2012) and integrated with the corrected flux to calculate the NEE. Following Law et al. (2002), NEE sign indicates whether the system is storing (negative) or releasing (positive) carbon. Details on data processing are given in Rana et al. (2016a).

Table 1. Soil characteristics in the experimental site.

\begin{tabular}{lcc} 
Parameter & Average & SD \\
Sand $\left(\mathrm{g} \mathrm{kg}^{-1}\right)$ & 21 & 0.6 \\
Silt $\left(\mathrm{g} \mathrm{kg}^{-1}\right)$ & 37 & 2.9 \\
\hline Clay $\left(\mathrm{g} \mathrm{kg}^{-1}\right)$ & 42 & 3.6 \\
$\mathrm{EC}\left(\mathrm{dS} \mathrm{m}^{-1}\right)$ & 0.6 & 0.1 \\
\hline $\mathrm{pH}$ & 7.9 & 0.3 \\
Field capacity $\left(\mathrm{m}^{3} \mathrm{~m}^{-3}\right)$ & 0.36 & 0.3 \\
\hline Wilting point $\left(\mathrm{m}^{3} \mathrm{~m}^{-3}\right)$ & 0.22 & 0.3 \\
$\mathrm{C}\left(\mathrm{g} \mathrm{kg}^{-1}\right)$ & 14 & 1.1 \\
\hline $\mathrm{N}\left(\mathrm{g} \mathrm{kg}^{-1}\right)$ & 1.5 & 0.2 \\
$\mathrm{P}\left(\mathrm{g} \mathrm{kg}^{-1}\right)$ & 71 & 3.1 \\
\hline
\end{tabular}

$\mathrm{SD}$, standard deviation; $\mathrm{EC}$, eddy covariance. 
Starting from EC data, hourly evapotranspiration, ET, was calculated by dividing LE by latent heat of vaporization $(L=2.45 \mathrm{MJ}$ $\mathrm{kg}^{-1}$ ) and at daily scale as sum of diurnal ET values.

The Marginal Distribution Sampling technique described in Reichstein et al. (2005) was employed for gap filling the time series of quality checked and filtered hourly flux: details of the procedure is reported in Rana et al. (2016a). Analyses at hourly and daily scales were carried out using only NEE and LE data flagged of good to excellent quality following Mauder and Foken (2004).

Net radiation $\left(R_{n}\right.$ in $\left.\mathrm{W} \mathrm{m}^{-2}\right)$ and soil heat flux $\left(G\right.$ in $\left.\mathrm{W} \mathrm{m}^{-2}\right)$ were measured by means of two net radiometers (model Q*6, Campbell Sci., Logan, UT, USA), $1 \mathrm{~m}$ above the top of the canopy, and two heat flux plates (FP-1, Campbell Sci.), placed at $0.1 \mathrm{~m}$ depth into the soil, respectively. These variables were collected by a CR10X (Campbell Sci., USA) data logger at a frequency of 0.1 $\mathrm{Hz}$ and stored for $1 \mathrm{~h}$ on average. Soil temperature in ${ }^{\circ} \mathrm{C}$ were measured at two depths $(2 \mathrm{~cm}$ below and $2 \mathrm{~cm}$ above each soil heat flux plate) with two thermo-resistances (PT100).

Quality of EC fluxes was assured by the energy balance closure (see Wilson et al., 2002 for a review). The sum of hourly values of turbulent fluxes $(H+\mathrm{LE})$ plus the storage terms was strongly correlated $\left(\mathrm{r}^{2}=0.79\right)$ with available energy $\left(A=R_{n}-G\right)$. Details of systematic error and the energy balance closure, total random flux uncertainty quantification, footprint analysis and NEE partitioning are reported in Rana et al. (2016a).

Hourly air temperature, relative humidity, precipitation, global $\left(R_{g}\right)$ and photosynthetically active radiation (PAR) were recorded from an automatic weather station located on grassland, approximately $100 \mathrm{~m}$ southwest of the EC station. After having analysed the precipitation data and compared them with data relative to the reference 31-year period (1979-2009), the season 2010-2011 was considered wet, while the season 2011-2012 was dry. Indeed, we considered the median of precipitation in the reference 31-year period in the major development plant period, from March until May, as threshold under which the growth season is dry (Hayes, 2006) and we observed that precipitations in March, April and May were equal to 51.6 in the reference period (median of precipitations in all these months in the 31-year reference period), while were equal to 93.9 and $23.1 \mathrm{~mm}$ (median of the precipitations in March, April and May) in the seasons 2010-2011 and 2011-2012, respectively (Table 2).
Even if continuous datasets for three entire growing seasons of cultivated cardoon are available and have been already deeply investigated in Rana et al. (2016a), in this study the analysis focuses on the period November-July of the two seasons - dry (DS) and wet (WS) - in order to i) compare homogeneous datasets in terms of number of data and ii) avoid periods when the crop was harvested and LAI was less than 1 (see Figure 2 in Rana et al., 2016a) which means the soil is almost bare.

\section{The water use efficiency and the canopy resistance}

Following Baldocchi (1994), Vanloocke et al. (2012), Zeri et al. (2013) and Li et al. (2015) the WUE ( $\left.\mathrm{gCO}_{2} \mathrm{kgH}_{2} \mathrm{O}^{-1}\right)$ at ecosystem scale is defined as the ratio between NEE and ET:

$$
W U E=\frac{N E E}{E T}
$$

The above mentioned authors also recommend the use of daytime data for computing WUE in order to relate it with carbon sequestration (Tubiello et al., 1999), then, in this work only daily values of NEE are considered, filtering data for $R_{g}>20 \mathrm{~W} \mathrm{~m}^{-2}$. Moreover, the term $\mathrm{CO}_{2}$ flux has been used to indicate the NEE during daytime.

In this study the cultivated cardoon stomatal regulation is determined by analysing the canopy resistance $\left(r_{c}\right.$ in s $\left.\mathrm{m}^{-1}\right)$ (Rana et al., 1997a, 1997b; Katerji and Rana, 2011). It is calculated by inverting the Penman-Monteith equation (Katerji and Rana, 2011):

$$
r_{c}=\left(\frac{\Delta A+\rho c_{p} V P D / r_{a}}{L E \gamma}-1\right) r_{a}
$$

where $\rho$ is the air density in $\mathrm{kg} \mathrm{m}^{-3}, \Delta$ is the slope of the saturation pressure deficit versus temperature function in $\mathrm{kPa} \mathrm{C}^{-1}, \gamma$ is the psychrometric constant in $\mathrm{kPa}^{\circ} \mathrm{C}^{-1}, c_{p}$ is the specific heat of moist air in $\mathrm{J} \mathrm{kg}^{-1}{ }^{\circ} \mathrm{C}^{-1}$. VPD is the vapour pressure deficit of the air in $\mathrm{hPa} . r_{a}$ is the aerodynamic resistance in $\mathrm{s} \mathrm{m}^{-1}$, calculated as proposed by Katerji and Rana (2011):

$$
r_{a}=\frac{\ln \left((z-d) / h_{c}-d\right)}{k u_{*}}
$$

Eq. 3

Table 2. Monthly mean air temperature $\left({ }^{\circ} \mathrm{C}\right)$, cumulated precipitation $(\mathrm{mm})$, evapotranspiration $\left(\mathrm{mm} \mathrm{month}^{-1}\right), \mathrm{CO}_{2} \mathrm{fluxes}\left(\mathrm{gCO}_{2} \mathrm{~m}^{-2}\right.$

\begin{tabular}{|c|c|c|c|c|c|c|c|c|c|c|c|c|}
\hline \multirow[t]{2}{*}{ Month } & \multicolumn{5}{|c|}{ 2010-2011 (WS) } & \multicolumn{5}{|c|}{$2011-2012$ (DS) } & \multicolumn{2}{|c|}{ 31-year mean } \\
\hline & $T_{\text {air }}$ & $\mathbf{P}$ & ET & NEE & WUE & $T_{\text {air }}$ & $\mathbf{P}$ & ET & NEE & WUE & $T_{\text {air }}$ & $\mathbf{P}$ \\
\hline November & 14.1 & 39.5 & 36 & -338 & -9.3 & 11.5 & 94.9 & 27 & -320 & -11.9 & 13.3 & 79.2 \\
\hline December & 9.2 & 33.0 & 29 & -265 & -9.3 & 9.5 & 15.2 & 30 & -353 & -11.8 & 9.8 & 76.4 \\
\hline January & 7.7 & 28.3 & 19 & -260 & -13.7 & 6.6 & 42.5 & 24 & -327 & -13.3 & 7.6 & 75.6 \\
\hline February & 8.0 & 29.2 & 31 & -424 & -13.6 & 5.7 & 72.4 & 26 & -285 & -10.8 & 8.6 & 71.6 \\
\hline March & 10.6 & 93.9 & 58 & -684 & -11.7 & 11.5 & 23.1 & 51 & -700 & -13.6 & 10.5 & 63.9 \\
\hline April & 14.2 & 139.7 & 88 & -977 & -11.1 & 13.6 & 45.3 & 83 & -864 & -10.4 & 13.4 & 51.6 \\
\hline May & 16.7 & 57.2 & 112 & -911 & -8.1 & 16.8 & 20.3 & 102 & -883 & -8.6 & 18.1 & 40.8 \\
\hline June & 22.7 & 34.7 & 78 & -116 & -1.5 & 23.6 & 1.9 & 72 & -208 & -2.9 & 21.7 & 39.5 \\
\hline July & 24.2 & 32.6 & 57 & 141 & 2.5 & 26.4 & 22.5 & 40 & 110 & 2.8 & 24.4 & 37.3 \\
\hline November-May & 11.5 & 420.8 & 373 & -3858 & -10.4 & 10.7 & 313.7 & 345 & -3732 & -10.8 & 11.6 & 459.1 \\
\hline November-July & 14.2 & 488.1 & 508 & -3833 & -7.5 & 13.9 & 338.1 & 456 & -3829 & -8.4 & 14.3 & 535.8 \\
\hline
\end{tabular}
month $\left.{ }^{-1}\right)$ and water use efficiency $\left(\mathrm{gCO}_{2} \mathrm{kgH}_{2} \mathrm{O}^{-1}\right)$ recorded in the experimental site during the two cultivated cardoon investigated time growth cycles - wet and dry - together with the mean reference values (1979-2009) of mean air temperature and cumulated precipitation.

WS, wet season; DS, dry season; $T_{\text {air }}$, mean air temperature; $P$, cumulated precipitation; ET, evapotranspiration (mm month ${ }^{-1}$ ); NEE, net ecosystem exchange; WUE, water use efficiency. 
where $z$ is the measurement height of wind speed, $k$ is the von Kármán constant, $h_{c}$ is the crop height and $d$ is the zero displacement plane height. All input variables are measured as indicated in Rana et al. (2016a), $\Delta$ is calculated as in Katerji and Rana (2011). LE and $u_{*}$ (friction velocity) are directly computed using EC data.

\section{Results and discussion}

\section{Seasonal and monthly scale}

\section{Weather}

Mean monthly air temperature and cumulated precipitation $(P)$ for the two growth seasons of the study are reported in Table 2, in comparison with the 31-year-reference period (1979-2009) means.

The mean temperature for the whole period is comparable with the temperature of the reference period, with exceptional hot summer in the DS (June and July 2012). In the two seasons the site received less water by precipitation than during the reference period: in particular, $9 \%$ and $37 \%$ less than the 31-year mean for WS and DS, respectively. The DS was drought in the spring period (March-June), with small rainfall in March, which is a crucial month for the development phase of the crop (Archontoulis et al., 2010). Furthermore, even if in the WS the site received an amount of water comparable with the 31-year mean, the rainfall distribution during the growth cycle was scarce during winter, from November until February, and very abundant in the spring, from March to May, with a huge value in April (171\% greater than the
31 -year value), representing the $29 \%$ of the total rain during the experimental period. In summary, the weather of the two seasons showed variability, being drought during spring-summer of the DS, and quite rainy during spring of the WS.

The total ET in the period November - July was 508 and 456 $\mathrm{mm}$ for the WS and DS, respectively. During DS rainfall exceeds ET only in November, January and February. Seasonal cumulated rainfall is lower than ET for the two seasons and the water deficits (ET- $P$ ) at the end of the growth cycles are equal to 20 and $118 \mathrm{~mm}$, for the WS and DS, respectively.

\section{Crop development}

A detailed description of the phenological phases development, the patterns of the green biomass (GB, g plant ${ }^{-1}$ ) and LAI $\left(\mathrm{m}^{2} \mathrm{~m}^{-2}\right)$ are reported in Rana et al. (2016a). The development of the green biomass reaches a first maximum on late November and January for the WS and DS, respectively, followed by a rapid decrease of the biomass in almost one month and a gentle increase until May and June for the WS and DS, respectively. The LAI has the same patterns as GB: the maximum value is reached on early May in the WS $\left(4.14 \mathrm{~m}^{2} \mathrm{~m}^{-2}\right)$ and on end May-early June in the DS $\left(4.54 \mathrm{~m}^{2} \mathrm{~m}^{-2}\right)$. The patterns of the LAI are clearly linked to the weather: the rainy spring accelerates the growth of the plants in the WS and, vice versa, the drought of the spring in the DS decelerates the development of cultivated cardoon crop.

\section{$\mathrm{CO}_{2}$ fluxes, evapotranspiration and water use efficiency}

Paths of NEE and LE during the day, as mean of hourly values month by month, are reported in Figure 1 for both the wet and dry

A

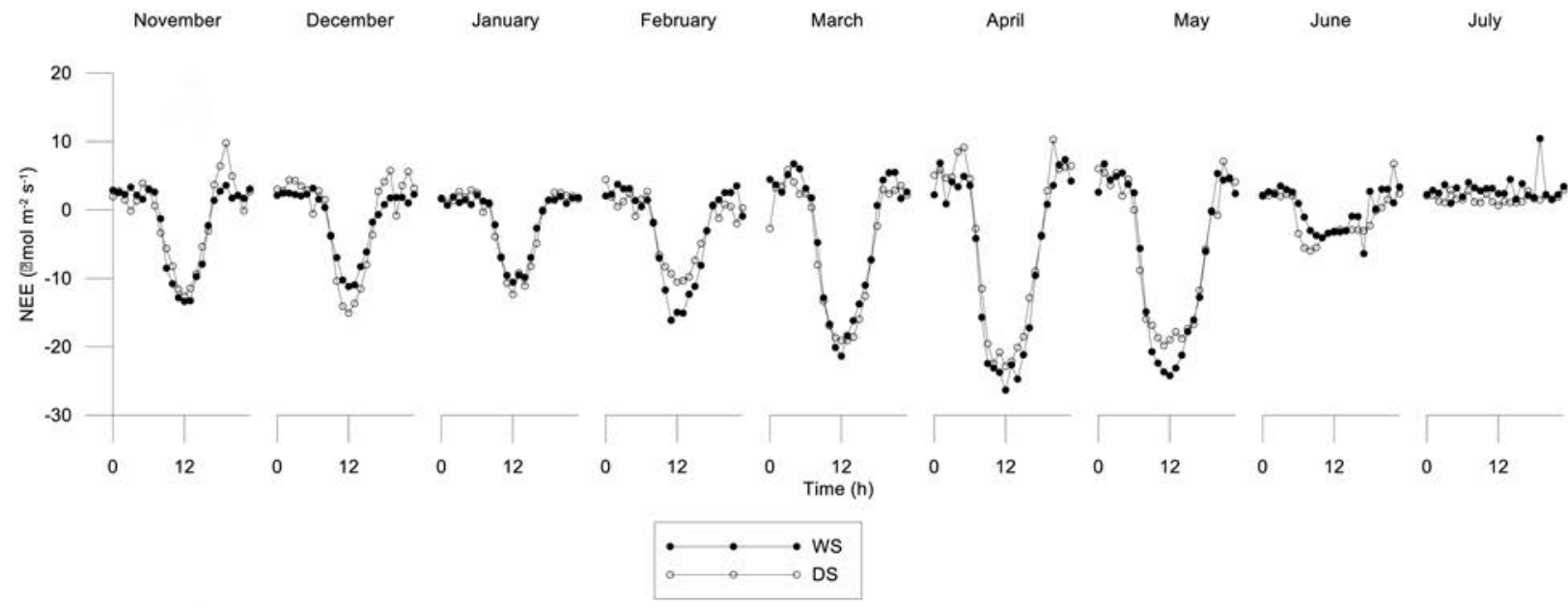

B

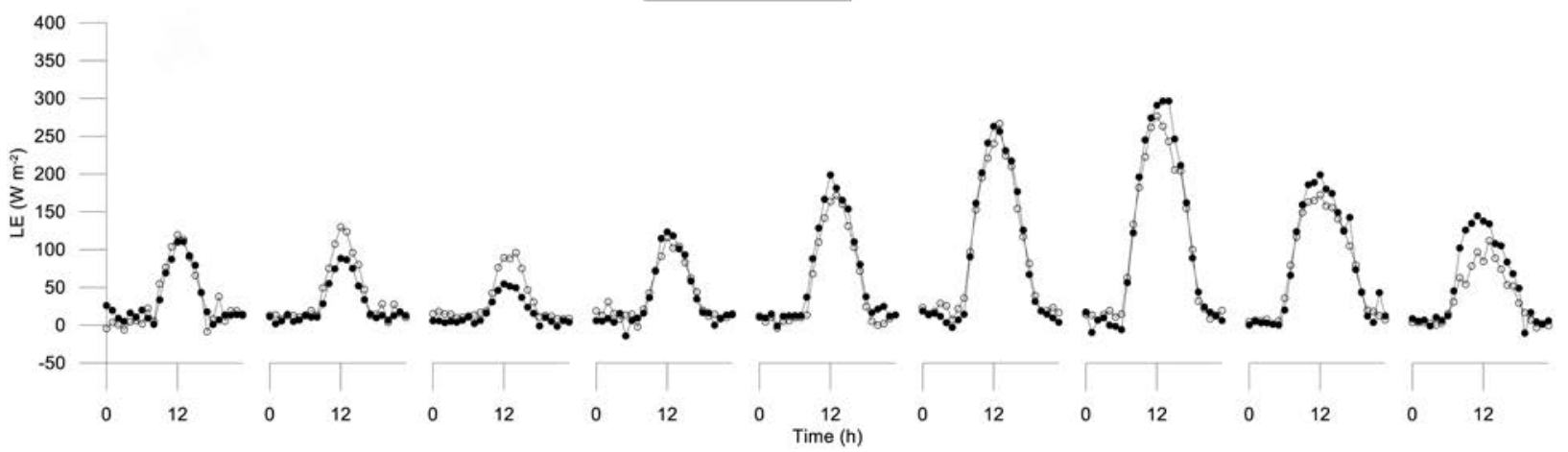

Figure 1. Diurnal trends of (A) net ecosystem exchange and (B) latent heat flux during time, from November until July for the two seasons: wet (November 2010-July 2011) and dry (November 2011-July 2012). 
season. Hourly trends of $\mathrm{CO}_{2}$ flux during the day follow the typical reversed sinusoidal dynamics with minimum values around noon (Figure 1A). $\mathrm{CO}_{2}$ flux decreases from November to January and increases from February until April-May, then it again decreases until the end of the season. The maximum value, both in terms of absolute and integral value, is reached in April, while $\mathrm{CO}_{2}$ flux is almost zero during July. The $\mathrm{CO}_{2}$ fluxes are very similar both in terms of pattern and values during the two seasons, even if the weather is substantially different, as above discussed. However, the $\mathrm{CO}_{2}$ flux is lower during the DS than in the WS during the whole cultivated cardoon growth cycle, except during winter and particularly in December and January, when it is slightly greater in the dry season than in the wet one, due to the different development of the crop (Rana et al., 2016a) and different meteorological conditions. Indeed, the DS winter is rainier than the WS one, making more water available for the cultivated cardoon growth. It seems that during the third growing cycle, the DS one, the crop improves its access to water reserve in deeper soil layers, which supports greater biomass and carbon assimilation than during WS, even if the precipitation pattern is unfavourable. Furthermore, the hourly values of NEE in the WS are very similar for the month of maximum growth of the cultivated cardoon (April and May) while in the DS they are lower in May than in April.

Hourly trends of latent heat flux during the day (Figure 1B) also follow the typical bell shape, being maximum around noon and minimum during nighttime or in the early morning. In the two growth seasons, the maximum integral value of LE is reached in May, when the LAI is around its maximum, while the lowest one is reached in January, when the air temperature is the lowest of the year. In general, the patterns of hourly LE is very similar in the two seasons, being almost superimposable from November until April, except for December and January, when the development of the crop is greater in DS than in WS. Differences can be envisaged in the LE pattern in May and June, when the crop evapotranspires more in the wet than in the dry season, confirming the results of other authors about the impact of rainfall distribution on evapotranspirative fluxes in function of phonological phases (Shurpali et al., 2013).

$\mathrm{LE}$ and $\mathrm{CO}_{2}$ fluxes greatly decrease in June and July, when the LAI and the GB decrease drastically due to the senescence of the crop and the photosynthetically active leaves are not yet fully functioning.

The seasonal and inter-annual pattern of LE and $\mathrm{CO}_{2}$ flux are deeply described in Rana et al. (2016a) and can be explainable both with the weather pattern and the plant physiology (see Figure 3 in Rana et al., 2016a). Instead, In this paper, WUE and its components NEE and LE have been studied at monthly, daily and hourly scale in function of crop and weather characteristics in order to investigate on if, how and why the cultivated cardoon crop changes its seasonal efficiency in the water use from wet to dry season of growth and what are the dynamics of water use and $\mathrm{CO}_{2}$ assimilation in function of crop physiological activities.

In Table 2 the cumulated ET, NEE and their ratio (i.e. the WUE) at monthly and seasonal scales are shown for both seasons. At monthly scale the WUE values are, generally, greater in DS than in WS, except in January when WUE values are almost equal and in February and April when it is higher in WS than DS. Moreover, WUE values are very low in June and positive in July for both seasons: this is due to the low value of NEE in June and its positive value in July, when the photosynthesis activity is almost zero due to senescence (Rana et al., 2016a). Actually, during the senescence the majority of $\mathrm{CO}_{2}$ fluxes are toward atmosphere due to respiration and so did not contribute to carbon assim- ilation. These values of WUE confirm the above observations of the hourly pattern of $\mathrm{CO}_{2}$ and latent heat fluxes.

Seasonal WUE, calculated as ratio of the cumulated values of NEE and ET, is of the same order in the two seasons but considerably higher $(+11.2 \%)$ in the dry season than in the wet one because the denominator (ET) is $10.2 \%$ lower than WS due to drought, while $\mathrm{CO}_{2}$ fluxes are identical. Excluding the months in which the crop is in the senescence phase (June and July, see Figure 1), the values of WUE are quite similar for the two seasons, being slightly higher $(+4.5 \%)$ in the dry season than in the wet one. During the period November-May, the ET and NEE of DS are smaller than those of the WS one by $7.5 \%$ and $3.3 \%$, respectively. In summary, taking into account the investigated time from November to July, the cumulated NEE are equal in the two seasons, while the cumulated ET is lower in the DS than in the WS. Instead, when the senescence is not taken into account, both cumulated NEE and ET are lower in the dry season than in the wet one and these differences are more marked for ET than for NEE. Therefore, the stomatal regulation, which affects both $\mathrm{CO}_{2}$ and $\mathrm{H}_{2} \mathrm{O}$ fluxes, seems to have more effect on NEE than on ET, as reported in Kuglitsh et al. (2008). For deeper investigating the significance and the causes of the differences in the seasonal WUEs and the relationships between NEE and ET in different meteorological conditions, the relationship between $\mathrm{CO}_{2}$ and water fluxes ET at different time scales has been analysed. Data relative to the senescence phase in June and July were excluded from this analysis for the aboveexplained reasons.

In Figure 2 monthly $\mathrm{CO}_{2}$ flux are related to ET values in the period November-May (Table 2). The slopes of these linear relationships forced to zero are a good representation of the WUE (Wagle and Kakani, 2012) and are very close to the WUE values found as ratio between NEE and ET, cumulated at seasonal scale in the same period. In this case the slopes are not significantly different (ANCOVA $\mathrm{P}=0.71$ ) even if the correlations are very strong.

It is worth to notice that the monthly relation between NEE and ET shows a plateau in April and May around $-900 \mathrm{gCO}_{2} \mathrm{~m}^{-2}$ month $^{-1}$ for both the seasons, which has to be investigated at smaller time scales.

\section{Daily scale}

Except for the senescence phase, in accordance with Emmerich (2007) and Wagle and Kakani (2012), daily WUE values along the seasons, show a great variability, ranging between -0.89 and $-41.68 \mathrm{gCO}_{2} \mathrm{kgH}_{2} \mathrm{O}^{-1}$ in the WS and between 0.12 and

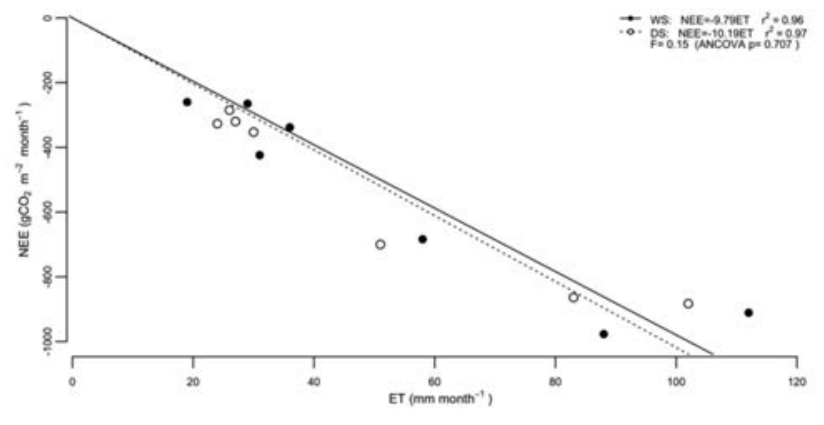

Figure 2. Water use efficiency at monthly scale as ratio between cumulated net ecosystem exchange and cumulated evapotranspiration in the period November-May (excluding the senescence phase) for the two seasons: wet (November 2010-July 2011) and dry (November 2011-July 2012). 
$-42.68 \mathrm{gCO}_{2} \mathrm{kgH}_{2} \mathrm{O}^{-1}$ in the DS. This variability is due to the effects of weather and plant physiology on $\mathrm{CO}_{2}$ and ET fluxes. The relation, using daily values, between diurnal cumulated $\mathrm{CO}_{2}$ flux and ET is shown in Figure 3. The reported values are relative to the months from November to May. For both considered datasets, the values are strongly linearly correlated, but the slopes of linear regressions, representing the WUEs at daily scale, are not significantly different (ANCOVA; $\mathrm{P}=0.095$ ). Furthermore, such as at monthly scale, the relationship between NEE and ET shows a plateau: at ET values greater than about $3 \mathrm{~mm} \mathrm{~d}^{-1}$ the crop does not assimilate more than about $-40 \mathrm{gCO}_{2} \mathrm{~m}^{-2} \mathrm{~d}^{-1}$.

The analysis continues at shorter time scale in order to investigate this apparent saturation of $\mathrm{CO}_{2}$ assimilation at high values of ET, found at monthly (Figure 2) and daily (Figure 3) scale, also considering that evapotranspiration (Katerji and Rana, 2011) and $\mathrm{CO}_{2}$ exchange are instantaneous phenomena (Steduto et al., 1997; Asseng and Hsiao, 2000). The seasonal and inter-annual change in the rate of photosynthesis for this cultivated cardoon crop is controlled by variation in amount of green leaf area (Rana et al., 2016a). The relationship between $\mathrm{CO}_{2}$ flux and LAI is often used to examine the role of leaf area in the crop water use at ecosystem level (Suyker and Verma, 2010; Li et al., 2015), for our case of study it is reported in Figure 4: each point represents the values of LAI and $\mathrm{CO}_{2}$ flux cumulated in the day when LAI is measured (10 and 11 sample days for WS and DS, respectively). Data relative to the senescence phase are excluded from the linear regression analysis, since only green leaves participate to the vapour and carbon dioxide stomatal regulation, as above reported. Note that the values relative to $\mathrm{LAI}<1$, when the crop did not cover completely the surface, are not taken into account in the linear regression of the two seasons. Notwithstanding a clear strong linear correlation between $\mathrm{LAI}$ and $\mathrm{CO}_{2}$ flux along the two seasons, Figure 4 shows that the $\mathrm{CO}_{2}$ flux reaches a sort of plateau for LAI values greater than about $3.5 \mathrm{~m}^{2} \mathrm{~m}^{-2}$ (dotted line), i.e. the plants seem not to improve their $\mathrm{CO}_{2}$ assimilation at high LAI values, during either the WS or the DS.

\section{Hourly scale}

The relationship between assimilation (diurnal $\mathrm{CO}_{2}$ flux in $\mu \mathrm{mol} \mathrm{m} \mathrm{m}^{-2} \mathrm{~s}^{-1}$ ) and evapotranspiration (in terms of positive diurnal instantaneous latent heat flux in $\mathrm{W} \mathrm{m}^{-2}$ ) at hourly scale, for both seasons are reported in Figure 5. Also at this time scale, the values are strongly linearly correlated, but the values of the slope of linear regressions between NEE and ET, representing the WUEs at hourly scale, are not significantly different (ANCOVA; $\mathrm{P}=0.314$ ). To understand the photosynthesis and water consumption of cultivated cardoon under different weather conditions and to interpret the shape of the relation between LAI and NEE (Figure 4) the following investigation at hourly scale is limited to a period of 15 days when the plants physiology are similar, i.e. same phenological phase (Rana et al., 2016a) and same LAI value of about $3.7 \mathrm{~m}^{2}$ $\mathrm{m}^{-2}$. These characteristics correspond to the following periods: 21 April - 5 May and 12- 26 May for the WS and DS, respectively. The mean diurnal values and standard deviations of PAR, VPD and $T_{\text {air }}$ are reported in Table 3, together with the number of cloudy days, calculated by the extra-terrestrial solar radiation and the actual global radiation as indicated by Law et al., (2002). The PAR is slightly higher in the DS than in the WS, because of the light distribution and the duration of the days of the chosen periods. The mean VPD is considerably higher in the DS than WS; however the dispersion of values is equal in the two seasons. Correspondingly, the mean air temperature in DS is higher than in WS with similar standard deviation.

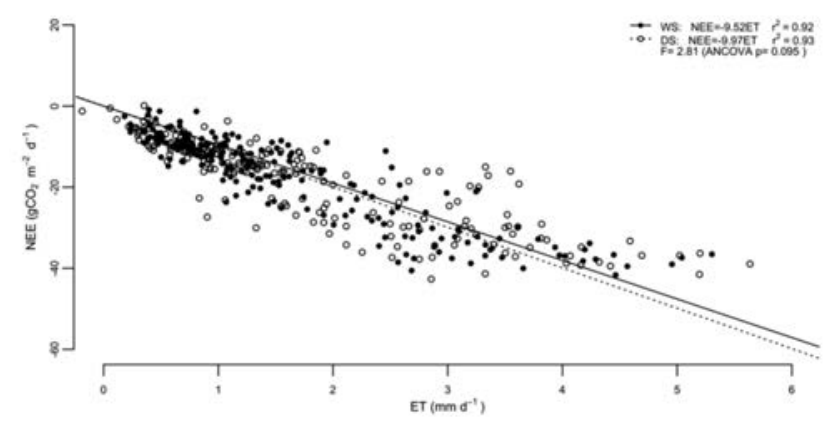

Figure 3. Water use efficiency as relationship at daily time scale between diurnal $\mathrm{CO}_{2}$ flux and evapotranspiration for the two seasons: wet (November 2010-July 2011) and dry (November 2011July 2012).

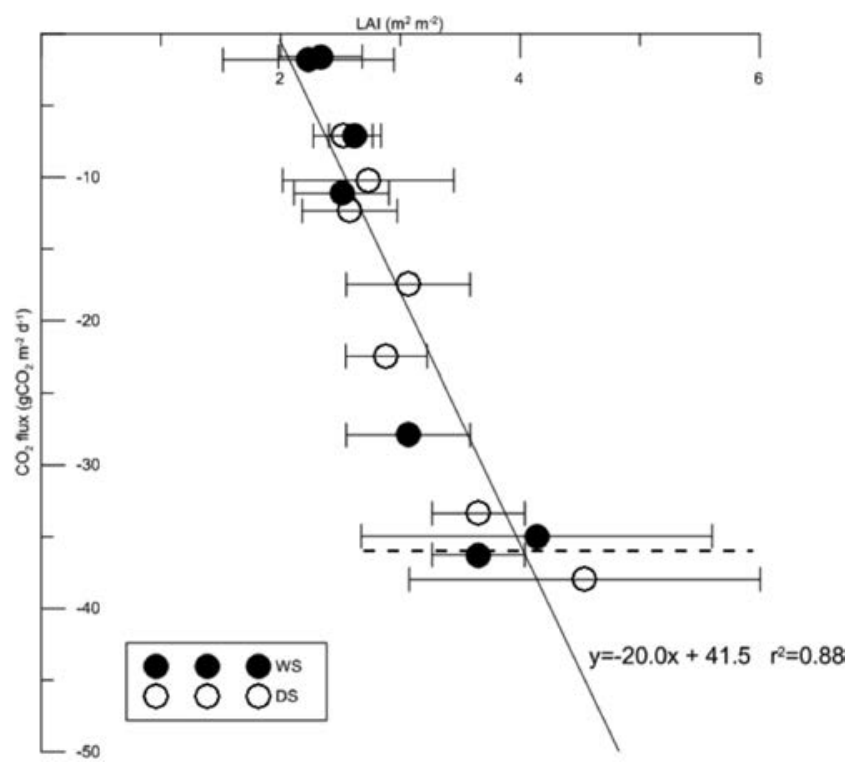

Figure 4. Relationship between leaf area index and $\mathrm{CO}_{2}$ flux for the two seasons: wet (November 2010-July 2011) and dry (November 2011-July 2012).

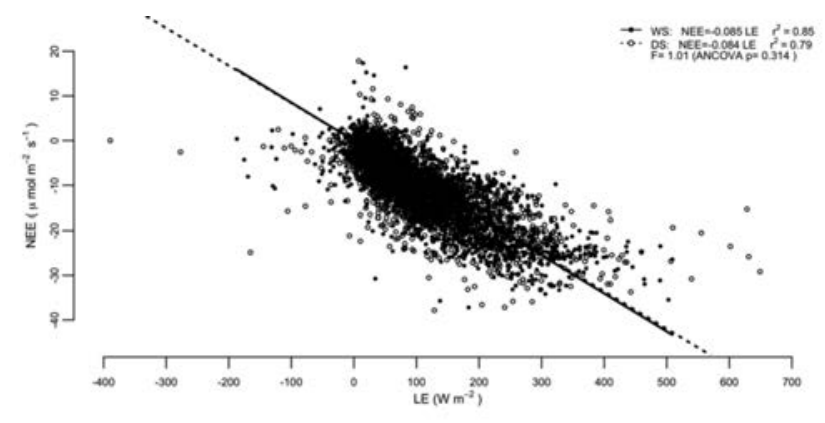

Figure 5. Relationship between $\mathrm{CO}_{2}$ flux and latent heat flux at hourly scale for the two seasons: wet (November 2010-July 2011) and dry (November 2011-July 2012). 
In Figure 6 the relationship between assimilation and latent heat flux is reported for the above mentioned selected 15 days of full plant physiological activity.

At hourly scale the relationships between NEE and LE are again strongly linear and the linear regressions are significantly different (ANCOVA; $\mathrm{P}<0.001$ ) with higher slope for WS than DS. These hourly relations show a plateau of $\mathrm{CO}_{2}$ at $\mathrm{LE}$ around 350 and $400 \mathrm{Wm}^{-2}$ for the WS and DS, respectively. Above these thresholds the mean values of NEE are $-26.7 \pm 3.9$ and $-24.1 \pm 5.8$ $\mu \mathrm{mol} \mathrm{m} \mathrm{m}^{-2} \mathrm{~s}^{-1}$ in WS and DS, respectively; the maximum NEE value attained by cultivated cardoon in the DS is lower than in the WS, even if the values are not significantly different.

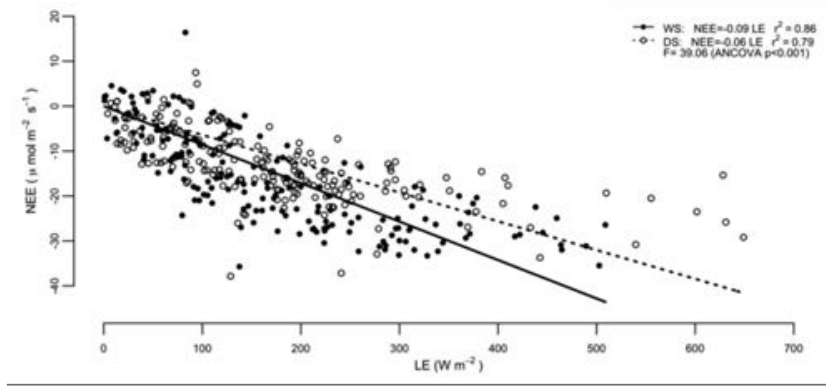

Figure 6. Relationship between $\mathrm{CO}_{2}$ flux and latent heat flux at hourly scale, in the 15 days around the peak of photosynthetic activity for the two seasons: wet (November 2010-July 2011) and dry (November 2011-July 2012).
It is reasonable to suppose that saturation of $\mathrm{CO}_{2}$ assimilation occurred when the plants exchange water vapour at high rate values: since $\mathrm{H}_{2} \mathrm{O}$ and $\mathrm{CO}_{2}$ fluxes are driven by the stomatal regulation, through light and thermodynamic conditions of the atmosphere, mainly VPD and air temperature (Monteith 1973; Rana and Katerji, 1998; Katerji and Rana, 2011; among many others), it is worth to investigate the influence of these variables on the $\mathrm{CO}_{2}$ assimilation and crop-air water vapour exchanges.

In Figure 7 the relationships among NEE (upper panels) and LE (bottom panels) vs PAR (a and d), VPD (b and e) and $T_{\text {air }}$ (c and f) are reported for both seasons. Meteorological variables are compiled with bins (Pingintha et al., 2010) having following values:

Table 3. Means of photosynthetically active radiation, vapour pressure deficit and mean air temperature considering only diurnal values in the selected period around full crop development for the two seasons - wet and dry.

\begin{tabular}{lcc} 
& WS, & DS, \\
& 21 April-5 May & 12-26 May \\
PAR $\left(\mathrm{MJ} \mathrm{m}^{-2} \mathrm{~h}^{-1}\right)$ & $1.71 \pm 1.25$ & $2.03 \pm 1.40$ \\
$\mathrm{VPD}(\mathrm{hPa})$ & $7.26 \pm 5.43$ & $10.06 \pm 5.68$ \\
\hline$T_{\text {air }}\left({ }^{\circ} \mathrm{C}\right)$ & $17.30 \pm 3.36$ & $18.67 \pm 3.89$ \\
Cloudy days $(\mathrm{n})$ & 10 & 5 \\
\hline
\end{tabular}

WS, wet season; DS, dry season; PAR, photosynthetically active radiation; VPD, vapour pressure deficit; $T_{\text {air }}$, mean air temperature.
A

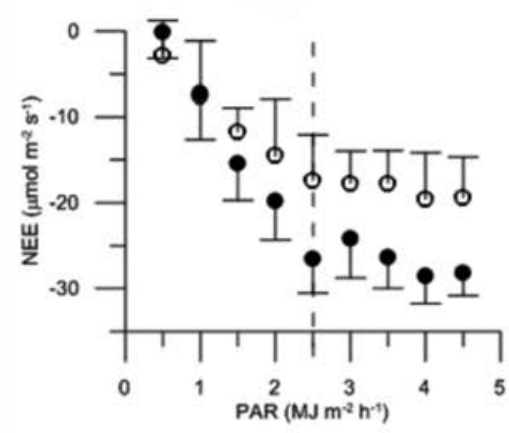

D

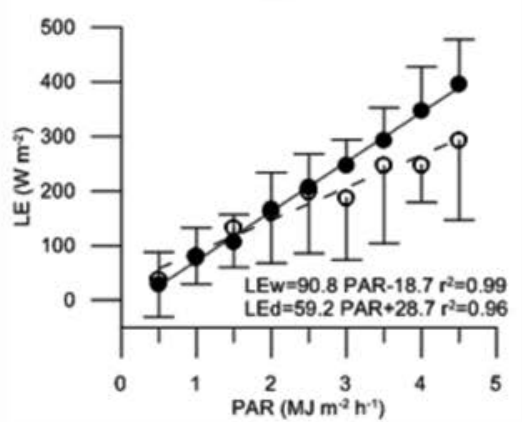

B
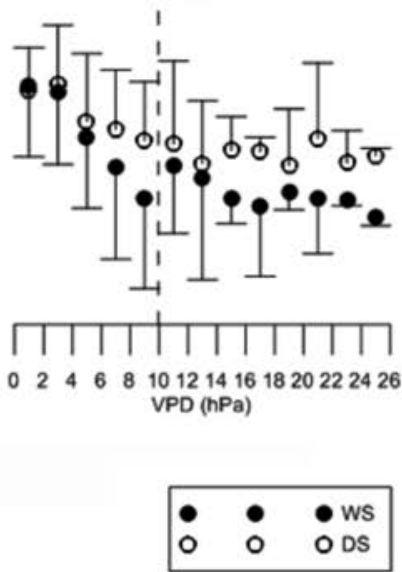

E

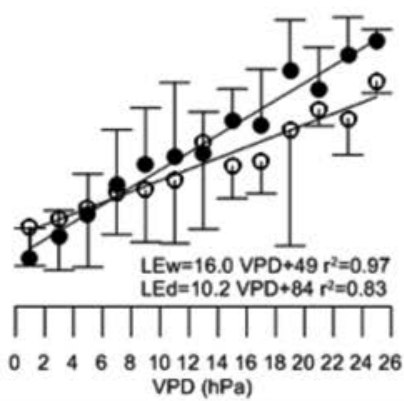

C

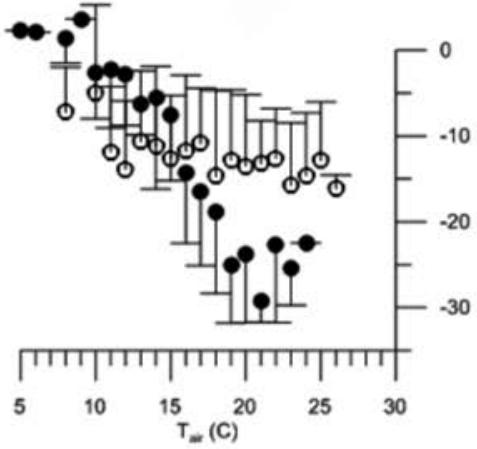

$\mathbf{F}$

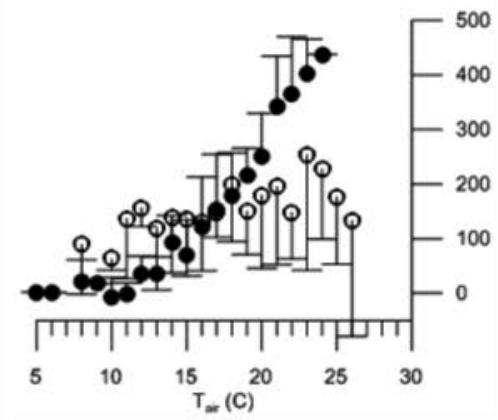

Figure 7. Relationships between net ecosystem exchange (A-C), latent heat (D-F) and climatic variables (photosynthetically active radiation, vapour pressure deficit, and air temperature) at hourly scale during the 15 days around the peak photosynthetic phase for the two seasons: wet (November 2010-July 2011) and dry (November 2011-July 2012). 
$0.5 \mathrm{MJ} \mathrm{m}^{-2} \mathrm{~h}^{-1}$ for PAR, $2 \mathrm{hPa}$ for VPD, $1^{\circ} \mathrm{C}$ for $T_{\text {air }}$. To avoid confusion due to superimposition in the graphic, the standard deviations are also indicated only in one direction, positive or negative; all data are relative to the above selected 15 days around the peak of photosynthetic activity.

The relationship between NEE and PAR (Figure 7A) is different in the two seasons: NEE linearly increases in absolute values with PAR until a threshold of $2.5 \mathrm{MJ} \mathrm{m}^{-2} \mathrm{~h}^{-1}$, then it remains constant around $-27 \mu \mathrm{mol} \mathrm{m} \mathrm{m}^{-2} \mathrm{~s}^{-1}$ in WS and $-18 \mu \mathrm{mol} \mathrm{m} \mathrm{m}^{-2} \mathrm{~s}^{-1}$ in DS. For low values of PAR the $\mathrm{CO}_{2}$ assimilation is only limited by light, while above a certain threshold at high values of light this limitation should be attributed to other factors (Bai et al., 2015), like VPD and soil moisture. Since photosynthesis is mainly regulated by light, these results are in general agreement with the relationships found in many other studies (see for example Nieveen et al., 2005), where a saturation value of PAR can be envisaged for the $\mathrm{CO}_{2}$ assimilation. Since the stomatal regulation is strongly influenced by the crop water status, this finding can be explained with the soil water conditions (Pingintha et al., 2010), which in the DS is far from optimum, due to the scarcity of rain in the period May-June 2012 (Table 2). The soil water scarcity determines the increase of the canopy resistance (Rana et al., 1997), which is associated to a decline of the photosynthetic rate (Williams et al., 2001).

The plants of cultivated cardoon show a similar, albeit significantly different, saturation of the $\mathrm{CO}_{2}$ assimilation at high PAR values for the two seasons, but this saturation is not revealed for the evapotranspiration, i.e. LE is not limited by increasing values of PAR and the relationships (Figure 7D) is strongly linear. Above the same PAR value of $2.5 \mathrm{MJ} \mathrm{m}^{-2} \mathrm{~h}^{-1}$, LE is lower in the DS than in the WS one. This different physiological response of the cultivated cardoon to the light for $\mathrm{CO}_{2}$ assimilation and evapotranspiration contributes to explain the differences found between WUE at seasonal and monthly scales observed above. Indeed, the different availability of soil water in the two seasons determines a sensitivity to PAR of cultivated cardoon crop greater for NEE than for LE, i.e. above a PAR saturation value, NEE attains a constant value lower in the dry season than in the wet one, while LE increases with PAR. Law et al. (2002) reported that the relation between NEE and PAR showed that crops absorbed more $\mathrm{CO}_{2}$ in cloudy days, which in our case occurs more often in WS than in DS (Table 2): during cloudy periods the soil moisture is higher, hence the soil respiration should be greater for the same values of PAR and $T_{\text {air }}$.

The relationship between $\mathrm{CO}_{2} / \mathrm{H}_{2} \mathrm{O}$ fluxes and VPD depends by stomatal regulation. The daytime hourly NEE (panel b) and LE (panel e) values are related to VPD in Figure 7. In both seasons, NEE increases in absolute value with VPD until a threshold of about $10 \mathrm{hPa}$ and it remains constant around -15 and $-20 \mu \mathrm{mol} \mathrm{m} \mathrm{m}^{-2} \mathrm{~s}^{-1}$ for WS and WD, respectively. Also for the relationships between LE and VPD the trends are similar and strongly linear, however, the slope of LE vs VPD is lower for DS than WS. Kuglitsch et al. (2008) reported that increasing VPD until afternoon causes stomatal closure, thus increasing stomatal resistance. Since stomatal resistance impacts on both $\mathrm{CO}_{2}$ assimilation and transpiration, but it is only the water flux to be proportional to VPD (Figure 7B and $7 \mathrm{E})$, the overall effect of VPD on NEE is higher than on transpiration. Furthermore, Körner (1995) and Unsworth et al. (2004) found a hysteretic pattern of diurnal NEE which was due to a limitation of photosynthesis caused by stomatal closure at high VPD. Actually, our results are in the same sense as Pingintha et al. (2010) who found a VPD saturation value of $12 \mathrm{hPa}$ above which NEE decreased toward constant value when a peanut crop is under water stress condition. Bai et al., (2015) reported that, for cotton,
$\mathrm{CO}_{2}$ assimilation increased with increasing VPD, reached the maximum over nearly $31 \mathrm{hPa}$ and then declined.

The relationships between NEE (panel C) and LE (panel F) and air temperature are reported in Figure 7. In WS, NEE increases with the increasing of $T_{\text {air }}$, then it remains almost constant around $21^{\circ} \mathrm{C}$; NEE in DS seems less affected by air temperature (Figure 7C). LE in WS monotonically increases with the increasing of $T_{a i r}$ above $11^{\circ} \mathrm{C}$; once again LE in the dry season seems less influenced by the $T_{\text {air }}$ pattern (Figure 7F). Pingintha et al. (2010) found the same trend for NEE after a value of $T_{\text {air }}$ of about $30^{\circ} \mathrm{C}$.

The variability of LE (deducible from standard deviation) is higher in the dry than in the wet season.

The influence of stomatal regulation on $\mathrm{CO}_{2}$ and $\mathrm{H}_{2} \mathrm{O}$ fluxes for cultivated cardoon crop was further and directly evaluated by studying the pattern of NEE and LE in function of the $r_{c}$. In Figure 8 the diurnal path of $r_{c}$ (panel A) is reported for both seasons together with VPD (panel B). Each point was calculated as the mean of all available data at that time. In both seasons, $r_{c}$ decreases from early morning until 8 a.m., then it remains almost constant until 2-3 P.m. reaching the lowest values around the hottest hours, then it increases until evening. During afternoon $r_{c}$ is always greater in DS than in WS; the VPD during DS is always higher than in WS (Figure 8B), but its influence on the $r_{c}$ is clearly effective in the afternoon, when $r_{c}$ has greater values, i.e. the stomata are more closed in DS than in WS.

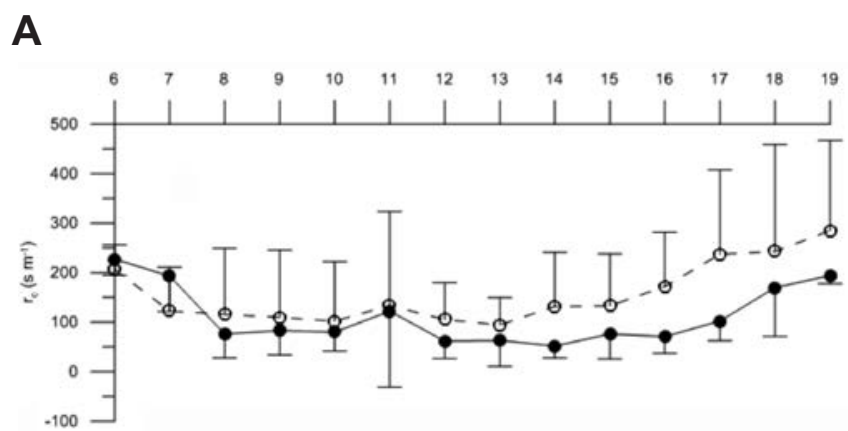

\section{B}

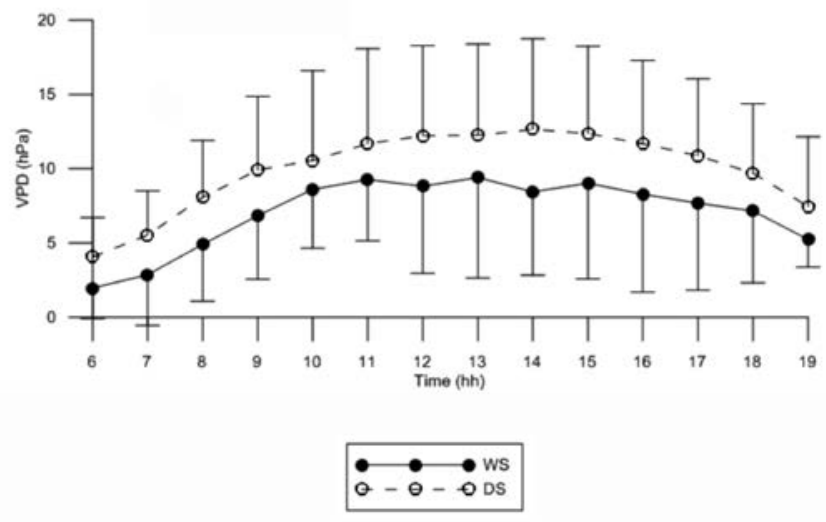

Figure 8. Diurnal trend of (A) canopy resistance and (B) vapour pressure deficit during the 15 days around the peak of photosynthetic activity for the two seasons: wet (November 2010-July 2011) and dry (November 2011-July 2012). 
The mean values of NEE (panel A), LE (panel B) and their ratio, WUE (panel C), are reported in function of canopy resistance in Figure 9, the values are compiled with $r_{c}$ bins of $50 \mathrm{~s} \mathrm{~m}^{-1}$. From this figure it is clear that the stomatal regulation has different impact on NEE and LE. LE linearly decreases with $r_{c}$ in both seasons (Figure 9B), while, NEE decreases as the canopy resistance increases in both wet and dry conditions, but the range of variation is lower for DS; in both seasons, however, NEE is constant for values of $r_{c}$ below a threshold of $100 \mathrm{~s} \mathrm{~m}^{-1}$ (Figure 9A). NEE is identical for both seasons when $r_{c}$ is around $150 \mathrm{~s} \mathrm{~m}^{-1}$, then it sharply decreases more during WS than during DS. The different impact of stomatal regulation on NEE and LE explains the pattern of WUE in function of the $r_{c}$ (Figure 9C): it remains constant below $r_{c}=150$ $\mathrm{s} \mathrm{m}^{-1}$, albeit at different values $\left(-0.11\right.$ and $-0.07 \mu \mathrm{molCO}_{2} \mathrm{~J}^{-1}$, for wet and dry season respectively), it is equal $(-0.09)$ when $r_{c}$ is around $200 \mathrm{~s} \mathrm{~m}^{-1}$ and it is greater in the dry than in the wet season for high values of $r_{c}$.

A

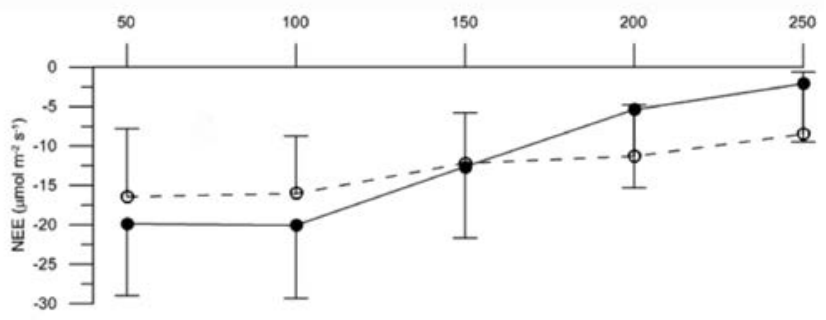

B

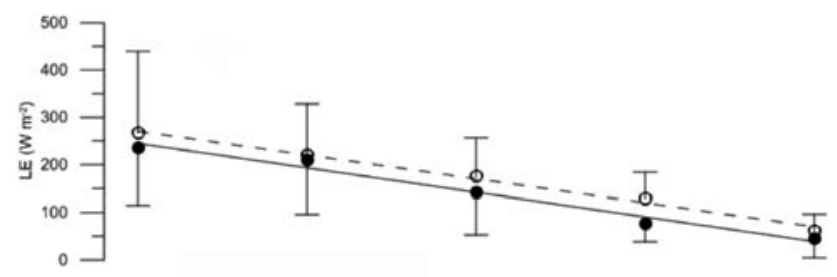

C

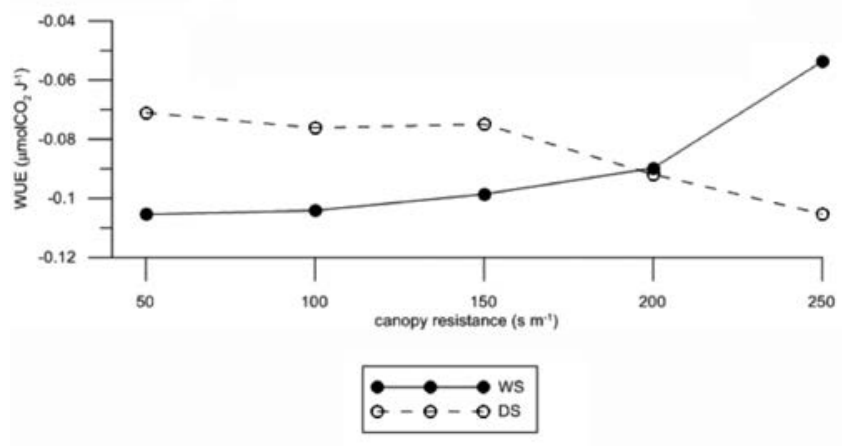

Figure 9. Relationships between net ecosystem exchange (A), latent heat (B) and water use efficiency (C) vs canopy resistance at hourly scale during the $\mathbf{1 5}$ days around the peak of photosynthetic activity for the two seasons: wet (November 2010-July 2011) and dry (November 2011-July 2012).

\section{Conclusions}

The cultivated cardoon, as perennial crop, spends one year, the first one after sowing, for its establishment investing mostly in developing the storage organs of root system, rather than in developing the above ground biomass (Angelini et al., 2009; Gominho et al., 2011; Rana et al., 2016a). The strong development of the root system supports the development of the green biomass in the seasons following the first one, when the cardoon crop showed similar physiological functioning, both in terms of phenological phases, green biomass and LAI development. Therefore, in the present study, the water relations, as water use efficiency (WUE), at ecosystem level was evaluated in the second and the third growth seasons, characterized by different climatic conditions: wet or dry as a consequence of the rainfall distribution. The analysis was performed at different temporal scales: seasonal, monthly, daily and hourly.

By excluding the period of senescence, WUE at seasonal scale was slightly higher in the dry season than in the wet one because of the reduction of crop evapotranspiration in the period of drought. Instead, the cumulated $\mathrm{CO}_{2}$ assimilation was similar in the two seasons. This finding was confirmed at monthly scale, but WUE was not significantly different in the two seasons. To investigate these results in function of the environmental drivers, the water use efficiency was investigated at shorter time scale. At daily scale cultivated cardoon plants reached a constant value of $\mathrm{CO}_{2}$ flux above $\mathrm{LAI}=3.5 \mathrm{~m}^{2} \mathrm{~m}^{-2}$, independently on the season. Moreover, at daily scale NEE showed a constant value at high ET, different for wet and dry seasons. This behaviour was investigated by analysing the relations between crop and climate (PAR, VPD and $T_{\text {air }}$. In fact, since photosynthesis is mainly regulated by light, a saturation value of PAR, common for both the seasons, was found for $\mathrm{CO}_{2}$, equal to $2.5 \mathrm{MJ} \mathrm{m}^{-2} \mathrm{~h}^{-1}$.

The analysis at hourly scale revealed also that NEE, LE and, consequently, WUE strongly depend on weather conditions and crop water conditions, which determine the stomatal regulation expressed through the canopy resistance.

By focusing on the period when the crop has the same value of LAI in both wet and dry conditions, a saturation value of $\mathrm{CO}_{2}$ flux for high values of PAR/VPD was found. However, the relationships between LE vs PAR and LE vs VPD were found linear. The crop limits $\mathrm{CO}_{2}$ assimilation at VPD over about $10 \mathrm{hPa}$ and, after this value, the photosynthesis was constant and on average lower in the dry season than in the wet one. Although drought causes reduction in photosynthesis and evapotranspiration by stomatal regulation, photosynthesis resulted surely the most sensitive to water stress.

As a consequence of our analyses, it can be said that the cultivated cardoon stomatal regulation optimizes the available water use in function of weather conditions. Hence, even if the rainfall is not well distributed in the growth season, also with extreme precipitation events, the rainfed cultivated cardoon regulates the exchanges of $\mathrm{CO}_{2}$ and $\mathrm{H}_{2} \mathrm{O}$ in order to have always a good efficiency of photosynthesis and water consumption. Therefore, it could be well adapted to climate change situations with low rainfalls and high temperature and vapor pressure deficit.

Finally, for practical purposes, since for rainfed crops the only water supply is rainfall, it was worth to compute also the precipitation use efficiency PUE (e.g. Huxman et al., 2004), given as the ratio between $\mathrm{NEE}$ and precipitations at seasonal scale: It was equal to -7.8 and $-11.3 \mathrm{gCO}_{2} / \mathrm{mmH}_{2} \mathrm{O}$ for the wet and dry season, respectively. The better performances in water use in the dry sea- 
son with respect to the wet one make Cynara cardunculus L. a suitable crop for sustainable cultivation in semi-arid water limited environments under rainfed conditions.

\section{References}

Angelini LG, Ceccarini L, Nassi o Di Nasso N, Bonari E, 2009. Long-term evaluation of biomass production and quality of two cardoon (Cynara cardunculus L.) cultivars for energy use. Biomass Bioen. 33:810-6.

Archontoulis SV, Struik PC, Vos J, Danalatos NG, 2010. Phenological growth stages of Cynara cardunculus: codification and description according to the BBCH scale. Ann. Appl. Biol. 156:253-70.

Asner GP, Archer S, Hughes RF, Ansley RJ, Wessman CA, 2003. Net changes in regional woody vegetation cover and carbon storage in Texas Drylands, 1937-1999. Global Change Biol. 9:316-35.

Asseng S, Hsiao TC, 2000. Canopy CO2 assimilation, energy balance, and water use efficiency of an alfalfa crop before and after cutting. Field Crop Res. 67:191-200.

Bai J, Wang J, Chen X, Luo GP, Shi H, Li LH, Li JL, 2015. Seasonal and inter-annual variations in carbon fluxes and evapotranspiration over cotton field under drip irrigation with plastic mulch in an arid region of Northwest China. J. Arid Land 7:272-84.

Baldocchi DD, 1994. A comparative study of mass and energy exchange rates over a closed C3 (wheat) and an open C4 (corn) crop: II. CO2 exchange and water use efficiency. Agric. For. Meteorol. 67:291-321.

Baldocchi DD, 2003. Assessing the eddy covariance technique for evaluating carbon dioxide exchange rates from ecosystems: past, present and future. Glob. Chan. Biol. 9:1-14.

Dai A, Trenberth KE, Qian T, 2004. A global dataset of palmer drought severity index for 1870-2002: relationship with soil moisture and effects of surface warming. J. Hydrometeor. 5:1117-30.

Emmerich WE, 2007. Ecosystem water use efficiency in a semiarid shrubland and grassland community. Rangeland Ecol. Manage. 60:464-70.

Giorgi F, Lionello P, 2008. Climate change projections for the Mediterranean region. Global Planet. Change 63:90-104.

Gominho J, Lourenço A, Palma P, Lourenço ME, Curt MD, Fernández J, Pereira H, 2011. Large scale cultivation of Cynara cardunculus L. for biomass production-A case study. Ind. Crop Prod. 33:1-6.

Grammelis P, Malliopoulou A, Basinas P, Danalatos NG, 2008. Cultivation and Characterization of Cynara Cardunculus for Solid Biofuels Production in the Mediterranean Region. Int. J. Mol. Sci. 9:1241-58.

Hayes MH, 2006. Drought indices. John Wiley \& Sons, Inc., New York, NY, USA.

Huxman TE, Smith MD, Fay PA, Knapp AK, Shaw MR, Loik ME, Smith SD, Tissue DT, Zak JC, Weltzin JF, Pockman WT, Sala OE, Haddad BM, Harte J, Koch GW, Schwinning S, Small EG, Williams DG, 2004. Convergence across biomes to a common rain-use efficiency. Nature 429:651-4.

Kaimal JC, Finnigan JJ, 1994. Atmospheric boundary layer flows - Their structure and measurements. Oxford University Press, Oxford, UK.

Katerji N, Mastrorilli M, Rana G, 2008. Water use efficiency of crops cultivated in the Mediterranean region: Review and analysis. Eur. J. Agron. 28:493-507.

Katerji N, Rana G, 2011. Crop reference evapotranspiration: a discussion of the concept, analysis of the process and validation. Water Res. Manag. 25:1581-600.

Katerji N, Rana G, Ferrara RM, 2017. Actual evapotranspiration for a reference crop within measured and future changing climate periods in the Mediterranean region. Theor. Appl. Climatol. 129:923-38.

Körner C, 1995. Leaf diffusive conductances in the major vegetation types of the globe. In: E.D. Schulze, M.M. Caldwell (eds.) Ecophysiology of Photosynthesis. Springer, Heidelberg, Germany. pp. 463-90.

Kuglitsch FG, Reichstein M, Beer C, Carrara A, Ceulemans R, Granier A, Janssens IA, Koestner B, Lindroth A, Loustau D, Matteucci G, Montagnani L, Moors EJ, Papale D, Pilegaard K, Rambal S, Rebmann C, Schulze ED, Seufert G, Verbeeck H, Vesala T, Aubinet M, Bernhofer C, Foken T, Gr"unwald T, Heinesch B, Kutsch W, Laurila T, Longdoz B, Miglietta F, Sanz MJ, Valentini R, 2008. Characterisation of ecosystem water-use efficiency of european forests from eddy covariance measurements. Biogeosci. Discuss. 5:4481-519.

Law BE, Falge E, Gu L, Baldocchi DD, Bakwin P, Berbigier P, Davis K, Dolman AJ, Falk M, Fuentes JD, Goldstein A, Granier A, Grelle A, Hollinger D, Janssens IA, Jarvis P, Jensen NO, Katul G, Mahli Y, Matteucci G, Meyers T, Monson R, Munger W, Oechel W, Olson R, Pilegaard K, Paw KT, Thorgeirsson UH, Valentini R, Verma S, Vesala T, Wilson K, Wofsy S, 2002. Environmental controls over carbon dioxide and water vapor exchange of terrestrial vegetation. Agric. For. Meteorol. 113:97-120.

Li S, Kang S, Zhang L, Du T, Tong L, Ding R, Guo W, Zhao P, Chen X, Xiao H, 2015. Ecosystem water use efficiency for a sparse vineyard in arid northwest China. Agric. Wat. Manage. 148:24-33.

Mauder M, Foken T, 2004. Documentation and instruction manual of the eddy covariance software package tk2. Available from: https://zenodo.org/record/20349/files/ARBERG062.pdf

Moncrieff JB, Massheder JM, de Bruin H, Elbers J, Friborg T, Heusinkveld B, Kabat P, Scott S, Soegaard H, Verhoef A, 1997. A system to measure surface fluxes of momentum, sensible heat, water vapour and carbon dioxide. J. Hydrol. 188189:589-611.

Monteith JL, 1973. Principles of environmental physics. Edward Arnold, London, UK.

Moureaux C, Ceschia E, Arriga N, Beziat P, Eugster W, Kutsch WL, Pattey E, 2012. Eddy covariance measurements over crops. In: M. Aubinet, T. Vesala, D. Papale (eds.) Eddy covariance: a practical guide to measurement and data analysis. Springer, Dordrecht, Germany.

Nieveen JP, Campbell DDI, Schipper LA, Blair IAJ, 2005. Carbon exchange of grazed pasture on a drained peat soil. Global Change Biol. 11:607-18.

Papale D, Reichstein M, Aubinet M, Canfora E, Bernhofer C, Kutsch W, Longdoz B, Rambal S, Valentini R, Vesala T, Yakir D, 2006. Towards a standardized processing of net ecosystem exchange measured with eddy covariance technique: algorithms and uncertainty estimation. Biogeosciences 3:571-83.

Pingintha N, Leclerc MY, Beasley Jr JP, Zhang DG, Senthong C, Rowland D, 2010. Hysteresis response of daytime net ecosystem exchange during drought. Biogeosciences 7:1159-70.

Polley HW, Morgan JA, Fay PA, 2011. Application of a conceptual framework to interpretvariability in rangeland responses to 
atmospheric CO2 enrichment. J. Agric. Sci. 149:1-14.

Rana G, Katerji N, 1998. A measurement-based sensitivity analysis of Penman-Monteith actual evapotranspiration model for crops of different height and in contrasting water status. Theor. Appl. Climatol. 60:141-9.

Rana G, Katerji N, Mastrorilli M, 1997. Environmental and soil-plant parameters for modelling actual crop evapotranspiration under water stress conditions. Ecological Modelling 101:363-71.

Rana G, Ferrara RM, Vitale D, D'Andrea L, Palumbo AD, 2016a. Carbon assimilation and water use efficiency of a perennial bioenergycrop (Cynara cardunculus L.) in Mediterranean environment. Agric. For. Meteor. 217:137-50.

Rana G, Muschitiello C, Ferrara RM, 2016b. Comparison between two monthly precipitation series recorded in Molfetta (south Italy) in the XVIII century (1784-1803) and at present days (1977-2015). Ital. J. Agrometeorol. (in press).

Reichstein M, Falge E, Baldocchi D, Papale D, 2005. On the separation of net ecosystem exchange into assimilation and ecosystem respiration: review and improved algorithm. Global Change Biol. 11:1-16.

Shurpali NJ, Biasi C, Jokinen S, Hyvönen N, Martikainen PJ, 2013. Linking water vapor and CO2 exchange from a perennial bioenergy crop on a drained organic soil in eastern Finland. Agric. For. Meteorol. 168:47-58.

Steduto P Katerji N, Puertos-Molina H, Unlu M, Mastrorilli M, Rana G, 1997. Water use efficiency of sweet sorghum under water stress conditions. Gas-exchange investigations at leaf and canopy scales. Field Crop Res. 54:221-34.

Suyker AE, Verma SB, 2010. Coupling of carbon dioxide and water vapor exchanges of irrigated and rainfed maize-soybean cropping systems and water productivity. Agric. For. Meteorol. 150:553-63.

Tallec T, Béziat P, Jarosz N, Rivalland V, Ceschia E, 2013. Crops' water use efficiencies in temperate climate: Comparison of stand, ecosystem and agronomical approaches. Agric. For. Meteorol. 168:69-81.

Tubiello FN, Lin G, Druitt JW, Marino BDV, 1999. Ecosystemlevel evapotranspiration and water-use efficiency in the desert biome of Biosphere 2. Ecol. Engin. 13:263-71.

Unsworth MH, Phillips N, Link T, Bond BJ, Falk M, Harmon ME, Hinckley TM, Marks D, Paw UKT, 2004. Components and controls of water flux in an old-growth Douglas-fir-western hemlock ecosystem. Ecosystems 7:468-81.

VanLoocke A, Twineb TE, Zeri M, Bernacchi CJ, 2012. A regional comparison of water use efficiency for miscanthus, switchgrass and maize. Agric. For. Meteorol. 164:82-95.

Vickers D, Mahrt L, 1997. Quality control and flux sampling problems for tower and aircraft data. J. Atmos. Oceanic Technol. 14:515-26.

Wagle P, Kakani VG, 2012. growing season variability in evapotranspiration, ecosystem water use efficiency, and energy partitioning in switchgrass. Ecohydrology 7:64-72.

Webb EK, Pearman G, Leuning R, 1980. Correction of flux measurements for density effects due to heat and water vapour transfer. Quart. J. Roy. Meteorol. Soc. 106:85-100.

Williams DG, Gempko V, Fravolini A, Leavitt SW, Wall GW, Kimball BA, Pinter PJ Jr, LaMorte RL, Ottman M, 2001. Carbon isotope discrimination by Sorghum bicolor under CO2 enrichment and drought. New Phytologist 150:285-93.

Wilson K, Goldstein A, Falge E, Aubinet M, Baldocchi D, Berbigier P, Bernhofer C, Ceulemans R, Dolmanh H, Field C, Grelle A, Ibrom A, Law KBE, Kowalski A, Meyers T, Moncrieff J, Monsonn R, Oechel W, Tenhunen J, Valentini R, Verma, S, 2002. Energy balance closure at FLUXNET sites. Agric. For. Meteorol. 113:223-43.

Yu G, Song X, Wang Q, Liu Y, Guan D, Yan J, Sun X, Zhang L, Wen X, 2008. Water-use efficiency of forest ecosystems in eastern China and its relations to climatic variables. New Phytologist 177:927-37.

Zhang Q, Manzoni S, Katul G, Porporato A, Yang D, 2014. The hysteretic evapotranspiration - Vapor pressure deficit relation. J. Geophys. Res. Biogeosci. 119:125-40.

Zeri M, Hussain MZ, Anderson D, Teixeira KJ, DeLucia E, Bernacchi CJ, 2013. Water use efficiency of perennial and annual bioenergy crops in central Illinois. J. Geophys. Res. Biogeosci. 118:581-9. 